\title{
Pope Innocent III, the Fourth Lateran Council, and Frankish Greece and Cyprus
}

Abstract: Although the union between the Latin and Greek Churches was one of Pope Innocent III's career-long ambitions, the limited provisions made by the canons of the Fourth Lateran Council regarding the eastern Churches has led most historians to assume that by the end of his pontificate this matter had been relegated to one of secondary importance and was treated only as an afterthought during the council. By collecting and re-examining the surviving sources, this article shows that considerable time and energy were spent during the council in regulating the affairs of the churches of former Byzantine lands. The ensuing decisions and legislation formed the basis of the organisation of the Church in much of the Greco-Latin East for at least another three centuries. 


\section{Pope Innocent III, the Fourth Lateran Council, and Frankish Greece and Cyprus}

\section{Chris Schabel and Nickiphoros I. Tsougarakis}

When Jean Richard traced the history of Cistercian Jubin Abbey on the Black Mountain in Syria and its ties with Frankish Cyprus, he could not have known that the monastery also held property on Venetian Crete in the early thirteenth century. ${ }^{1}$ The register that may have contained Pope Innocent III's confirmation of Jubin's possessions, dated 24 September 1215, does not survive, and the Archivio di Stato di Genova's copy from 1456 is incomplete, listing in full only Jubin's still accessible incomes from Cyprus. ${ }^{2}$ The only known mention of the Cretan holding, in a letter of Pope Honorius III dated 22 November 1223 and surviving in a copy in the Archivio di Stato di Venezia, was intentionally obliterated in Flaminio Cornelio's work on the church of Torcello, published in Venice in 1749: 'the abbey of Jubin on the Black Mountain of the Cistercian Order' was changed to 'the abbey of San Tommaso di Torcello of the Cistercian Order on the Black Mountain'. ${ }^{3}$ Perhaps after the monks of Jubin had taken refuge in Genoa that city's rival, Venice, really did give Jubin's Cretan property to San Tomasso di Torcello, but Cornelio's edition is nevertheless a forgery. No doubt he mistakenly thought that 'the Black Mountain' was on Crete, lost to the Ottomans in the seventeenth century, so he changed the syntax accordingly. It was only through a check of Cornelio's transcription in situ in 2014 that his forgery was detected, but this probably would not have been necessary had Innocent's register survived.

The loss of the papal registers covering the seventeenth, eighteenth, and nineteenth years of Innocent III's reign, from 22 February 1214 until his death on 16 July 1216 , constitutes a general problem for European historiography, but it is a catastrophe for places where contemporary archives do not survive, such as the Latin East. In particular, the high 
attendance at the Fourth Lateran Council, which convened on 11 November 1215 and met until the end of the month, must have generated an extraordinary amount of work for the papal chancery, since every prelate and magnate who made the trip or sent an envoy would have wanted to take care of business. Yet few of the council's canons deal directly with matters pertaining to the Church in the Greco-Latin East, leading most historians to infer that, by the time the council convened, the issue had become secondary for the pope and the council treated it almost as an afterthought. Colin Morris, for instance, concluded that the pope 'continued to assume that the Latin conquest had provided a definitive solution to interchurch relations and made no serious attempt to seek for new initiatives in the Lateran Council'. ${ }^{4}$ R. J. Cleary, in a study devoted to Innocent's relations with the Greeks, asserts that the council neglected the Greek Church and that by 1215 the matter of Church union had faded into insignificance. ${ }^{5}$

Other sources, however, often misdated or overlooked, help us to fill in the unfortunate gap for the history of Frankish Greece and Cyprus and they tell a different story. Some of Innocent's pertinent letters survive independently of the registers - although they have usually been dated wrongly to the period before Lateran $\mathrm{IV}^{6}$ - and we also possess a list of some of the participants at the council, rubrics for many letters of Innocent's last year, and Pope Honorius III's letters. These sources demonstrate that the pope and the delegates from the East expended considerable time and energy at the council in regulating the affairs of the Church in former Byzantine lands.

Evaluating their decisions in terms of Innocent's policy after the conquest of 1204 is complicated, because there is no consensus among historians about what that policy was. ${ }^{7}$ According to an older and rather extreme view, in the eyes of the papacy the conquest de facto achieved the union of the Churches, a process of converting the Greeks to Latin Christianity in both rite and doctrine was initiated, and this conversion was to be completed 
under a strictly Latin episcopal hierarchy by the missionary activity of the Cistercians. ${ }^{8}$ From this perspective, one would interpret the papal and conciliar decisions of late 1215 and early 1216 outlined below as lacking in ambition, an admission of failure. Recent research has shown, however, that once Innocent was fully informed about the nature of the conquest, the pope adopted a pragmatic policy, avoiding doctrinal and ritual issues, trying to maintain Greek bishops in sees that were predominantly Greek in population, and defending Greek monasteries, as long as the prelates took the standard oath to the pope and the Roman Church. ${ }^{9}$ Although partly successful, this policy was frustrated, on the one hand, by Latin lords desiring Latin bishops and monasteries and, on the other, by many Greek bishops and abbots refusing to take the oath. Seen in this light, the documents from Lateran IV reflect continuity in Innocent's intense interest in the former Byzantine lands and in his particular policy toward the Greeks, with some success regarding Greek monasteries and a clever device allowing for the appointment of Greek vicars. As in his general policy in the East, Innocent's successor Honorius III largely implemented Innocent's decisions from the time of Lateran IV, which in many ways formed the basis of the organisation of the Church in much of the Greco-Latin East for the following three centuries.

On 19 April 1213 Pope Innocent III wrote to the prelates and sovereigns of Latin Christendom announcing a Universal Council to be held in Rome on 1 November 1215, two and a half years hence. ${ }^{10}$ Innocent ordered the archbishops, bishops, abbots, and priors to attend, but to leave one or two suffragan bishops in each province to carry out the ministry. Cathedral chapters were to send provosts or deans and the kings and emperors were to designate nuncios to attend the council. The copy in the papal register records the addressees in Romania and Cyprus: ${ }^{11}$ besides the emperor of Constantinople and the king of Cyprus, although not the king of Thessaloniki, ${ }^{12}$ the letter was addressed to the prelates of the 
province of Cyprus and to those of every single European province, except that the chancery forgot to write 'Thebes' in the register: Crete; Patras and Corinth in the Principality of Achaia; Athens in that lordship (Thebes being missing); Neopatras (now Ypati), Larissa, Thessaloniki, Serres, and Philippi in the Kingdom of Thessaloniki; and Adrianople, Herakleia, Vrysis, and Constantinople itself on the European side of the Empire of Constantinople. ${ }^{13}$ In addition to fifteen provinces (counting Thebes), the letter to the vacant see of Constantinople apparently also covered the Asian archdioceses, since it was addressed to 'both the Latin and the Greek archbishops, bishops and abbeys throughout the province of Constantinople'.

Over a century ago, Achille Luchaire found a manuscript in Zurich with a list of the prelates who actually attended (we fill in the names using other sources): ${ }^{14}$ from Cyprus, Archbishop [Eustorge] of Nicosia and Bishop [Caesarius] of Famagusta; from the Principality of Achaia, Archbishop [Antelm] of Patras with Bishops [John?] of Modon, [Eudes of Villehardouin] of Coron, and [Hugh?] of Nikli, and Archbishop [Walter] of Corinth with the bishop of Argos; from the Lordship of Athens, Archbishop [C.?] of Athens with the bishops of Avlonari and Negroponte (both outside the lordship, in Negroponte), and Archbishop [Hardouin] of Thebes with the bishop of Kastorion (today's Thisvi, not Kastoria); from the Kingdom of Thessaloniki, Archbishop [Warin] of Thessaloniki, Archbishop [John] of Neopatras, and Bishop [Bartholomew] of Gardiki representing the province of Larissa; from the Empire of Constantinople, Patriarch [Gervase] of Constantinople, Archbishop [Nicholas?] of Herakleia, and Archbishop [John?] of Mytilene. That is, the archbishop of Nicosia and eight European metropolitans, in addition to that of Mytilene in the eastern Aegean, plus nine suffragan bishops, of which the bishop of Gardiki represented another European archdiocese. Thus two thirds of the provinces specified in 1213 were represented. Geography and stability seemed to have played a role: except for 
Famagusta on distant but secure Cyprus, all of the suffragan bishops came from sees in the relatively safe far south of Greece, on or near the coast. Foreshadowing their future demise, the areas north and east of Gardiki and Neopatras, representing the majority of Romania at its greatest extent, sent a mere four prelates out of nineteen. The absence of Cretan prelates is perhaps striking, but the Venetian colonisation of Crete had only just started in 1211. Candia already had in residence a Latin archbishop, whose career was less than exemplary, but being a faithful Venetian citizen and therefore inclined to cooperate with the Venetian regime of Crete, he may have avoided attending the council. ${ }^{15}$ Many of the prelates of mainland Greece, in contrast, were locked in dispute over ecclesiastical matters with the lay authorities, which would have provided a good incentive to make the journey.

The decisions of the council itself were of paramount importance for Romania and Cyprus, but there is evidence that the representatives of former Byzantine lands did take care of business. In 1863 Augustin Theiner published the rubrics of some letters from the lost registers of Innocent III, from a manuscript now known as Reg. Vat. 8A. Of these, two concern Cyprus and between thirty-five and forty - depending on the identification of proper nouns - involve Romania. ${ }^{16}$ Of the letters whose rubrics Theiner had printed, in 1902 Karl Hampe published the full text of twenty-five of them from the end of Innocent's reign surviving undated in a formulary in a Paris manuscript, six of which concern Romania and Cyprus. ${ }^{17}$ Hampe dated these six approximately to January 1216 , and another whose full text survives elsewhere was composed on 23 January 1216 (see below). These seven letters fall between numbers 63 and 95 on this section of Theiner's list. The first one of interest on Theiner's list, number 14, is the rubric for the letter discussed above listing those who attended the Fourth Lateran Council, while the second pertinent letter, number 22, Innocent's somewhat amusing account of his transfer of the relics of yet another St Dionysius to SaintDenis, also survives complete and is dated 4 January 1216, although Migne misdated it to 
1215. On the other end, we have the complete text of the fourth to the last pertinent one on Theiner's list, number 118 to Otto de la Roche, dated 12 January 1216, again misdated by its editor to $1215 .^{18}$ Judging from their relative position in Reg. Vat. 8A, between numbers 14 and 122 , we can safely assume that all of the rubrics pertaining to Romania and Cyprus are from letters composed in January 1216. Another surviving letter, confirming the Teutonic Knights' privileges and possessions, among them a property in Cyprus, is dated 18 February 1216 (also misdated to 1215$) ;{ }^{19}$ its absence from Theiner's list suggests that the rubrics in Reg. Vat. 8A for the year 1216 all date from 1 January to mid-February. That is, all of these three dozen or so texts concerning Romania and Cyprus come from the immediate aftermath of the council itself. It should be noted that only a fraction of papal letters made it into the registers, so the actual number of letters that Innocent composed concerning Romania and Cyprus around the time of the council was probably much higher.

At least two secular rulers from Romania seem to have used the council as an opportunity to improve ties with the papacy. Otto de la Roche, lord of Athens, had granted the castle of 'Lavadia' (Livadeia) in his lordship to the Roman Church via Cardinal Pelagius, papal legate in Romania, who granted it back to Otto as a fief, making Otto the Church's liege and man, liable to paying the Apostolic See two marks annual rent. On 21 June 1214 Pelagius wrote the clerics of the church of the castle, taking the castle, church, and its rights and property under papal protection, exempting it from episcopal and other jurisdiction, and granting them the tithes of the people of the castle and casale of 'Lavadia'. On 12 January 1216 Innocent III wrote Otto confirming the arrangement, which explains why Honorius could write to the clergy of 'Livadia' Castle in 1223, taking them, their property, and what Pelagius had conceded them under papal protection. At the same time Innocent III thanked Count Matthew of Cephalonia and Zakynthos for the fifty hyperpera he donated to the Roman Church, 
confirming the count's conditional bequest that, if he died without legitimate heirs, the Roman Church should possess and freely dispose of his goods. ${ }^{20}$

Religious institutions and individuals used the council to secure papal protection, such as the 'praepositus' of Constantinople, either the provost of the church of Constantinople or one of the priors of the various collegiate churches of the capital, who had a say in the election of patriarch. Likewise, Archdeacon James of Corinth obtained confirmation of his position. The master and brothers of the Hospital of St Sampson of Constantinople received confirmation for their hospital and their goods, although they had to pay three hyperpera annually for the papal protection they sought. ${ }^{21}$

Finally, several Greek-rite monasteries from across the Balkans (and perhaps also the Holy Land) gained concessions from the pope. Canons 53 and 55 of Lateran IV enjoined that Greek monasteries should pay tithes, which was not a Greek tradition. A number of Greek monasteries must have had representation at the council, because several received tithe exemptions soon afterward. In Acta Innocentii III, presumably concerning non-Latin houses, Haluscynskyj included the exemption that five monasteries received for lands that the monks cultivated with their own hands, with Innocent taking the abbeys and their possessions under papal protection as well: St Demetrius, SS Cosmas and Damian, St Luke de Stirio ('Strio' in the manuscript and in Theiner), St Theodosius de Montesegor, and St Demetrius of the Greeks of Hungary, although Haluscynskyj skipped St Demetrius super Sabam. With the Greek monastery of St Luke of Stiris (Hosios Loukas) in the Lordship of Athens, we have evidence from Honorius III's time that the abbot was using his protection and exemption to escape all episcopal control. ${ }^{22}$ Haluscynskyj does not mention six other possibly Greek abbeys to which Innocent granted an unspecified tithe exemption: Holy Apostles de Mireno, St Mary Costhime, that of dompnus Meletius, Holy Savior de Sagniaca, St Mary Agriotisse and one referred simply as de Campis. We cannot be certain how many of these monasteries 
were situated in Romania and Cyprus, but most of them probably followed the Greek rite. Besides St Luke of Stiris, we know that dompnus Meletius was Greek-rite, since 'following the example of Pope I[nnocent III]', in 1218 Honorius wrote to the abbot and monks of Hosios Meletios of Mt Myoupolis, taking them, their monastery, and their possessions under papal protection and, because the Greeks did not have the tradition of paying tithes, he confirmed their exemption on lands that they possessed before Lateran IV. ${ }^{23}$ St Mary Agriotissa was also certainly located in Romania or Cyprus, although its location is unknown. ${ }^{24}$ There is some debate over whether St Demetrius of the Greeks in Hungary and St Demetrius super Sabam are in fact one and the same house, that of St Demetrius of Sremska Mitrovica (ancient Sirmium), on the Sava River, in modern-day Serbia. ${ }^{25}$ If so, then the papal curia must have remained in confusion over this for a while, for the two monasteries reappear side by side in a letter of Honorius III, dated October 1216, confirming the privileges and possessions of St Theodosius de Laberia, which is understood as the monastery of St Theodosius in Palestine, near Bethlehem. ${ }^{26}$ Given that St Theodosius de Laberia appears in the same document as the two SS Demetrii in the Kingdom of Hungary (indeed it seems to own them) and one of the privileges confirmed is, again, a partial exemption of tithes, St Theodosius de Laberia was probably the St Theodosius de Montesegor that appears on our list. Later still, in 1218 Honorius granted a further tithe exemption to the brothers of St Theodosius. ${ }^{27}$ The Holy Apostles de Mireno, St Mary Costhime, the monastery de Campis and the Holy Saviour de Sagniaca are harder to identify, but since they appear listed among demonstrably Greek abbeys, it seems reasonable to assume that they too were Greek-rite monasteries, even if they were not located within Romania. ${ }^{28}$ The nature of the exemptions granted to these houses can also be surmised, if those mentioned above are any guide.

Greek monasteries continued to function while in the possession of Latin institutions, as was probably the case with St Phocas in Constantinople. Cardinal Benedict apparently 
granted St Phocas to the dean and chapter of St Michael of Boukoleon (a collegiate church in the capital) when legate in Romania in 1205-1207, but when Cardinal Pelagius, bishop of Albano, was legate in 1213-1214 he brokered an agreement over St Phocas between Boukoleon and Cistercian St Angelus Abbey in Constantinople. It is, therefore, perplexing that just after Lateran IV Innocent III wrote to the dean and cantor of St Mary of Blachernae (another collegiate church) and the prior of Langurio, confirming the agreement between them, on one side, and St Angelus, on the other, over St Phocas. Yet in the next rubric, Innocent ordered the bishop of Selymbria to carry out certain tasks that Pelagius had assigned him concerning the case between the deans and chapters of Boukoleon and Blachernae, which may have involved St Phocas. Since the bishop of Selymbria was also told to absolve the deans and chapters from laying violent hands on clerics (unless the infractions were very serious), it appears that the dispute became physical. If St Phocas was the focus of the quarrel, the bishop of Selymbria found in favour of Boukoleon, since Honorius III wrote three pertinent letters for Boukoleon in April 1217. ${ }^{29}$

In his letter of April 1213, Innocent stated that two things were most dear to his heart, the recovery of the Holy Land and the reform of the Church, the latter being the motivation for the council. The attendance of both prelates and members of cathedral chapters meant that Innocent informed himself of the internal problems of the churches of Romania. The rubrics of two letters from January 1216 record that Innocent instructed the new Patriarch Gervase and Archbishop Hardouin and a canon of Thebes, the first two and perhaps all three still in Rome, to enforce a sentence against three other attendees, Archbishop Walter of Corinth, Bishop Bartholomew of Gardiki, and the bishop of Kastorion, all described as 'criminals'. The sentence must have involved their actual deposition, since the addressees were to enjoin on their chapters to provide their churches with 'good persons'. In particular, we learn that 
Archbishop Walter was a monk and was to be forcibly returned to the cloister whence he came. ${ }^{30}$

Honorius III's letters provide some confirmation of these actions. In April 1217 Honorius wrote that Innocent III had removed Bishop Bartholomew from Gardiki because of certain charges, no doubt brought to the pope's attention at the council. The former bishop of Gardiki, too, was to become (again?) a monk, although Honorius compromised somewhat on his removal. In early April 1218 we learn that the bishop of Coron had become archbishop of Corinth after Honorius' assumption of the papacy in the summer of 1216, so it is probable that Innocent's will was also done in the case of Corinth. Regarding Kastorion, we first hear of it in February 1218, when because of the bishop's poverty Honorius granted him the bishopric of Avlonari on Negroponte, whence Innocent III had removed the bishop of Davleia, although the latter bishop remained there with patriarchal support. Whether the bishop of Kastorion was the 'criminal' bishop's replacement or not, we do not know. Perhaps Innocent tried to deal with the bishop of Davleia at or soon after the council as well, but many papal letters were never entered into the registers. The same is the case with the notorious Archbishop Antelm of Patras, another participant at Lateran IV, who was only punished in 1224, after a long series of attempts by Honorius. In June 1224 Honorius began his letter describing Antelm's crimes and punishment thus: 'When repeated complaints concerning our venerable brother Archbishop [Antelm] of Patras, which had climbed to the Apostolic See from the time of our predecessor, Pope Innocent of happy memory, finally very frequently battered our ears...' With Antelm, we know that members of his chapter sought his punishment, and they would have had a representative at Lateran IV. Certainly some of the people later assigned to investigate Antelm were there. ${ }^{31}$

One of the first canons of Lateran IV, number 5, officially pronounced that Constantinople ranked first after Rome, a theory that we find evolving in Innocent's registers following the 
capture of Constantinople, which also featured prominently in the contemporary debates and polemical writings between Latin and Greek prelates. ${ }^{32}$ During the council itself Innocent made Archbishop Gervase of Herakleia the second Latin patriarch of Constantinople, filling a see that had been vacant for years following Thomas Morosini's death. Unless the list of attendees counts Gervase twice, both as patriarch and archbishop of Herakleia, Innocent probably named the next metropolitan of Herakleia, perhaps the $\mathrm{N}$ [icholas?] who resigned in 1223. Soon after Gervase's appointment, in January 1216 Innocent granted Gervase the pallium and many normal privileges, along with others that survive in rubrics. Although when he received the pallium Gervase had taken an oath not to sell, alienate, give, or pawn possessions belonging to his patriarchal demesne, Innocent allowed him to do so when useful for his church, with the advice of prudent men, without consulting the pope. Innocent's successor, Honorius, would later accuse Gervase's successor, Matthew, of doing exactly this, so Matthew did not inherit Gervase's indulgence. Innocent also granted that Gervase could absolve forgers of his and his church's seals and those who laid violent hands on clerics, except in serious cases, and while Honorius objected when the patriarch absolved those who abused bishops, he renewed the privilege for Matthew. Gervase was also allowed to anoint the emperors of Constantinople, although Honorius crowned Emperor Henry's successor, apologising to Gervase. In addition, Innocent gave the patriarch permission to promote worthy persons to subdeacon on Sundays and especially solemn days and to invest people in ranks with the insignia of their offices. Sending the patriarch on his way, Innocent ordered the archbishops, bishops, and other prelates subject to the church of Constantinople to obey Gervase. A year after Gervase's return from the council, however, Honorius III had to tell the prelates of the city and diocese of Constantinople, whom Gervase had represented at Lateran IV, to pay for the patriarch's expenses incurred in Rome. ${ }^{33}$ 
Innocent also dealt with issues of the chapter at Lateran IV. He confirmed the number of thirty-five canons and forty prebends in the church of Constantinople, which Cardinal Giovanni Colonna would reduce to thirty-eight prebends while legate in 1218-1221 and which Honorius further decreased to twenty-four prebends in 1225 , because of the continual decline of the empire and the church's economic situation. Innocent instructed Patriarch Gervase to provide Archdeacon M. of Constantinople with a benefice, so he could afford the necessities of life, noting that the legate Pelagius had granted the archdeacon certain incomes in 1213-1214. Since the office of archdeacon had not been active in the Latin period, Innocent also granted the archdeacon that he could use his office in accordance with canon law, which use was significant, because the pope went on to urge all clerics of the diocese of Constantinople to receive the archdeacon kindly when he made visitations (in accordance with canon 3 of Lateran IV). ${ }^{34}$

Innocent apparently put all the churches of Constantinople in order around the time of the council. According to a letter of Honorius III dated July 1218, the dean and chapter of Boukoleon claimed that, while legate, Cardinal Pelagius had granted them the church of Arkheion 'until that and other churches of the city of Constantinople would be arranged on apostolic authority'. The bishop-elect of Arkheion countered that, since 'the provision of the churches of Constantinople was arranged in the General Council', he was elected canonically. Because the papal letter (of Innocent?) that Boukoleon obtained in its favour made no mention of the arrangement done at the council, the bishop-elect argued that Boukoleon's letter was invalid. ${ }^{35}$

Unfortunately, we do not know exactly what Innocent decided for the capital's ecclesiastical institutions in general, although from an early letter of Honorius III we learn that, at Emperor Henry's request, Innocent established and confirmed a provision for the churches of Constantinople of a twelfth of all possessions located in the Empire of 
Constantinople proper (east of the border with the Kingdom of Thessaloniki), belonging both to churches and laypersons. Patriarch Gervase also claimed that Innocent had ordered, again at the emperor's request, that a twelfth of the possessions of the emperor himself and his barons and knights be given to the churches of Constantinople. ${ }^{36}$

Perhaps Innocent approved this arrangement at the council, but as the details of the attendance at the council discussed above suggest, by late 1215 things were not going well for the empire. Emperor Henry must have sent nuncios as requested, and he also figures in some of the letters that followed. Aside from granting the emperor the right to hear offices in the imperial chapel of Constantinople while under interdict, Innocent's letters present an already dark picture. The pope ordered three unnamed bishops to hear the case that Henry was bringing against certain people who were contesting the rights he had in some monasteries, to compel certain barons and nobles to pay the emperor the rights and incomes that they owed him, and to stop some of the same barons from claiming for themselves the rights on regalia belonging to the emperor. ${ }^{37}$

Innocent also tried to comfort Emperor Henry regarding his present poverty during hard times, while urging him to defend the churches against the incursions of evil men. ${ }^{38}$ Henry's financial troubles and those of the empire in general may have caused some foot dragging on the part of the nobles, however. Innocent exhorted Henry to implement an arrangement over tithe payments in his lands, and the pope addressed a letter to Patriarch Gervase to induce the emperor to carry it out. ${ }^{39}$ Neither the agreement over the twelfth nor the tithe arrangement was enforced, however, and in August 1217 Honorius III explained to Gervase that he had suspended the churches' lawsuit concerning the issue, citing the crisis in the empire following Henry's death and the capture of his successor, Peter of Courtenay, as well as the papal legate, by Despot Theodore of Epirus. Honorius noted that nobles might not risk fighting the enemies while excommunicated because of the property dispute, so he had the sentence 
against them relaxed. It is unclear when exactly the sentence was promulgated and by whom. Gervase could not have arrived in Constantinople until early June 1216, since he issued a charter in Corinth on 29 May. ${ }^{40}$ According to Honorius, Innocent wrote to Emperor Henry with some instructions and gave certain judges the authority to promulgate the sentence, which they did, since Henry had neglected to follow Innocent's orders. In further explaining his actions to Gervase, Honorius noted in private that by the time the mandate reached the judges who promulgated the sentence, both Henry and Innocent had died, in June and July respectively, so legally the case had no parties. ${ }^{41}$ Given the sequence of events, Innocent must have addressed the emperor and judges in the last months of his reign.

While we do not have many details concerning the arrangements for the empire proper, we know precisely what was proposed for the Kingdom of Thessaloniki, Negroponte, and the Lordship of Athens. In May 1210 at Ravennica, near the border of Thessaloniki and Athens, the ecclesiastical and secular authorities of Romania came to an agreement for the territory between the eastern confines of the Kingdom of Thessaloniki until Corinth. The text of the wide-ranging pact, which involves property, serfs on ecclesiastical land, taxes, the lower Greek clergy, and other matters, has been widely known for centuries, since it was incorporated into a letter of Honorius III from 1223 containing a revised agreement for the Principality of Achaia. ${ }^{42}$ It is less known that a previous letter of Honorius, dated early 1219 , also contains the Ravennica accord, but this time as part of Innocent III's confirmation. Innocent explains that, after Ravennica, Cardinal Pelagius, while legate in Romania in 12131214 , actually made arrangements that were to the detriment of the churches. Thus Innocent confirmed the Ravennica agreement instead and extended it to all areas further west, including Achaia and, should it be conquered in the future, Epirus. Honorius' letter containing Innocent's confirmation was printed by Spyridon Lampros in an obscure Greek publication in 1906, but it was later printed in more accessible editions, in Acta Innocentii III 
and Acta Honorii III. These two publications date the letter to 25 and 23 January 1215 respectively, well before the Fourth Lateran Council, despite the fact that Innocent himself, just before quoting the agreement, states: ${ }^{43}$ 'We also add that, according to what was recently established at the holy General Council, tithes should be paid to the churches in full, both by Greeks and Latins.' In fact, the 1215 date was merely a miscalculation on the editors' part: the letter actually dates to 23 January 1216 and corresponds to Theiner's rubric number 86 :

\footnotetext{
'It is written to the patriarch of Constantinople and various other archbishops, and a certain agreement from a while ago, concerning the resignation of churches and monasteries done by the nobles, princes, and barons residing from the border of the Kingdom of Thessaloniki until Corinth into the hands of G. [read T], former patriarch of Constantinople, is confirmed, and the text of the agreement is inserted. ${ }^{44}$
}

That is to say, it was at Lateran IV that Pope Innocent III arranged for all major aspects of ecclesiastical-secular relationships for the whole of the Empire of Constantinople and its vassal states.

Indeed, Innocent did the same for important questions of Church structure. The rubric of one letter grants that, acting in conjunction with the legate, Patriarch Gervase can unite bishoprics in Romania. This is exactly what happened: when the legate Cardinal Giovanni Colonna arrived in Romania after Despot Theodore released him from captivity, one of his early reports to Honorius III included - besides the information that the archdeacon of Negroponte was allowing people to trade with Alexandria, against the Holy Land decrees of Lateran IV - recommendations on the unification of dioceses. Honorius responded in August 1218 that the cardinals had escaped the summer heat of the Eternal City and he could not 
decide alone, and it was not until March 1222 that Honorius approved the absorption of some fifteen bishoprics into neighbouring sees. ${ }^{45}$

It could be argued that the most ambitious reforms for Frankish Greece and Cyprus are reflected in the decisions of the council itself. To an extent, of course, all seventy canons of the council applied to the former Byzantine territories now under Latin rule, and the Holy Land decrees affected Romania and Cyprus more than most places, because both areas were considered vital for the crusading effort. One might think that canon 1, affirming the Filioque, was inspired by and directed at the Greeks, but canon 2 makes it clear that Ioachim of Fiora's understanding of the Trinity was the target of the first canon, ${ }^{46}$ while there is no evidence that the popes tried to impose the Filioque on the Greeks in Romania or Cyprus. Likewise, canon 1's assertion that there is one Universal Church outside of which there is no salvation was intended mostly for western heretics.

Some canons applied specifically to the former Byzantine lands, however. Canon 5, we have seen, officially made the patriarch of Constantinople second in rank after the pope, and in his letter confirming and extending the Ravennica agreement Innocent interpreted the council's decrees on tithes to apply to all Greeks as well as Latins. This explains the council's choice of words in the beginning of canon 53: 'In some regions there are intermingled certain peoples who by custom, in accordance with their own rites, do not pay tithes, even though they are counted as christians. ${ }^{, 47}$ This caution is also present in how Lateran IV phrased the most important pronouncement on the Greeks relating to doctrine, canon 4:

\footnotetext{
'Although we would wish to cherish and honour the Greeks who in our days are returning to the obedience of the apostolic see, by preserving their customs and rites as much as we can in the Lord, nevertheless we neither
} 
want nor ought to defer to them in matters which bring danger to souls and detract from the church's honour. ${ }^{48}$

Yet the council did not attack the Greeks' doctrine or rites, but only their rejection of Latin rites, forbidding on pain of excommunication and deposition Greeks from washing altars after their use by Latins, 'as if the altars had been defiled thereby', and from rebaptising those who had already received the sacrament from Latins.

Finally, canon 9 made an important structural change. Innocent had hoped that Greek bishops would remain in place under Latin rule and take the ordinary oath to the Roman Church, at least in areas where the population remained overwhelmingly Greek. The local secular rulers in Frankish Greece seem to have had other ideas, however, although some Greek bishops remained in the Kingdom of Thessaloniki, ${ }^{49}$ a parallel Greek hierarchy had been left in place in Cyprus, and Van Tricht ${ }^{50}$ has recently proposed that some of the bishops in the empire proper were Greeks as well, which would explain Innocent's 1213 letter to 'both the Latin and the Greek archbishops and bishops and abbeys throughout the province of Constantinople'. In a separate publication Van Tricht has shown that the Greek metropolitan of Adrianople certainly remained in place after the Latin conquest of the city. ${ }^{51}$

The evidence for the existence of Greek bishops in the empire proper is actually stronger than Van Tricht recognised. Three letters addressed by members of the Greek clergy to Innocent in the period 1206-1213/4 attest to this. The first, written in the aftermath of the death of Patriarch John Kamateros in June 1206, petitions the pope to allow the Greek clergy to elect its own patriarch in Constantinople. ${ }^{52}$ In doing so, it refers to the letter's authors as bishops (’’ $\rho \chi \varepsilon \rho \varepsilon \tilde{~} \varsigma)$. The second letter, undated and usually attributed to the period of Pelagius' legation in 1213-1214, may actually predate the convocation of Lateran IV, since it does not refer to the summons. ${ }^{53}$ This letter is often cited as evidence of the Greek clergy's 
fidelity to Emperor Henry, but it is worth noting that, again, the authors refer to themselves as co-bishops of the Latins. Basileios Pediadites, metropolitan of Corfu, wrote the final letter, probably late in 1214 , as a direct response to Innocent's inviting the Greeks to the council. ${ }^{54}$ In a sarcastic tone different from that of the two letters composed by clergy under Latin dominion, Pediadites declares Innocent personally responsible for the removal of the Greek 'western' bishops (i.e., those of mainland Greece), implying that the bishops of the empire proper had remained in place. Although only Pediadites' letter directly related to Lateran IV, all three bear witness to the continuity and constancy of the Greek clergy's demands: with the election of a Greek patriarch as a pre-condition for the convocation of an ecumenical council, all three imply (or state) that only through discussion of doctrinal differences at such a council could the two Churches truly be united. In demanding a Greek patriarch alongside the established Latin one, the Greeks were essentially asking for two parallel hierarchies in Constantinople, the precise issue that canon 9 would address, although clearly not in the way that the Greeks were hoping.

Canon 9 began by remarking that, 'in many places peoples of different languages live within the same city or diocese, having one faith but different rites and customs'. ${ }^{55}$ The council ordered the bishops of these areas to appoint 'suitable men' to administer to those people. Although the same city and diocese could not have more than one bishop, Lateran IV urged that the Latin bishop should appoint a 'prelate' as his vicar for the subject population of a different rite and language.

The canon certainly precluded the possibility of a Greek patriarch in Constantinople, but we do not know how it was implemented in the empire proper or in the Kingdom of Thessaloniki, in part because within a few years the latter had disappeared completely and the former had shrunk to a tiny area around the capital. Farther south, however, Bishop John of Negroponte assigned a Greek vicar to the church of Oreoi, which Giovanni Colonna had 
joined to Negroponte. This sort of arrangement may have occurred in other locales in Romania, but we only learn of this instance because the Latin bishop of Oreoi complained that the bishop of Negroponte had tricked the legate into uniting the churches, according to a letter of Honorius III from January 1224 recording the complaint. ${ }^{56}$

The most significant consequence of canon 9 was the reorganisation of the church in Cyprus. From the installation of a Latin hierarchy in 1196 until 1222, four Latin bishops (including the archbishop of Nicosia) existed side-by-side with fourteen or fifteen Greek bishops (with their archbishop). The experienced Cardinal Pelagius was now acting as legate on the Fifth Crusade and in Cyprus. In effect, in brokering a revised agreement between the ecclesiastical and secular authorities in Cyprus parallel to those reached in Romania, Pelagius managed in one blow to bring Cyprus into compliance with canon 9 and to eliminate poor dioceses, as Giovanni Colonna was accomplishing on the mainland. In September 1222 all but four of the Greek bishoprics were eliminated and the remaining four had their episcopal seats in places different from the Latin ones, although the dioceses were co-extensive. The four Greeks who served their Greek flocks retained the title of bishop, but they were subordinated to their Latin counterparts, becoming in a sense their vicars. This was to be the ecclesiastical organisation of Cyprus for the next 350 years, down to the Ottoman conquest of 1571.57

According to a myth that developed around the time of the Ottoman conquest, Queen Alice of Cyprus, a teenager, wrote to Innocent III at the Fourth Lateran Council, requesting that he relieve the tension between the Latin and Greek clergies on Cyprus. ${ }^{58}$ The loss of the papal registers for the end of Innocent III's reign means that we will never be informed about the precise background to his initiative on Cyprus, but the stray sources at our disposal do tell us that, rather than a single response to a young queen, it was part of a comprehensive reform 
programme that involved all the former Byzantine territories conquered by the Franks in the course of the Third and Fourth Crusades, a programme that Innocent implemented with the help of his successor, Honorius III, and two legates, Giovanni Colonna and Pelagius, all of whom participated in the Fourth Lateran Council. ${ }^{59}$ Far from neglecting the Church in the former lands of the Byzantine Empire, Lateran IV actually represents the culmination of Innocent's efforts to stabilise and regulate it, following the ad hoc experimentation of the lay and ecclesiastical authorities in the period immediately after the conquest. A significant number of prelates from the Greek lands attended the council, seeking to resolve the problems arising in their sees and monasteries, while the canons of the council also legislated on some of the major issues resulting from the implantation of the Latin Church in Romania, such as the payment of tithes and the status of the Greek episcopacy. Naturally, some of the solutions adopted represent compromises, but this was in keeping with Innocent's careful approach to the matter of Greco-Latin coexistence. The disappearance of a portion of Innocent's registers, along with the general scarcity of sources from Latin Romania, has meant that much material has been irretrievably lost. The careful collation of the surviving sources, however, can still offer new insights and help us correct the often distorted image of the ecclesiastical affairs of those lands.

\footnotetext{
${ }^{1}$ On Jubin, see Jean Richard, 'L'Abbaye cistercienne de Jubin et le Prieuré Saint-Blaise de

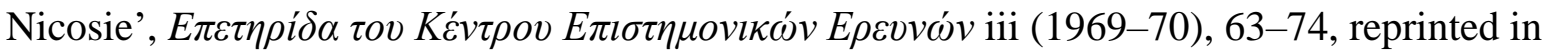
Jean Richard, Orient et occident au Moyen Age: contacts et relations (XII $-X V^{e}$ s.), London 1976, no. XIX.

${ }^{2}$ Published in A. Ferretto, 'Contributi alle relazioni tra Genova e l'Oriente. Una lettera del Pontefice Innocenzo III e un privilegio di Guido, re di Gerusalemme e signore di Cipro',
} Giornale Ligustico xxi (1896), 40-8, at 43-4, reproduced in Bullarium Cyprium, vol. I: Papal 
letters involving Cyprus 1196-1261, ed. Chris Schabel with an historical introduction by Jean Richard (Texts and Studies in the History of Cyprus, 64.1), Nicosia 2010, no. b-42.

${ }^{3}$ Flaminio Cornelio, Ecclesiae Torcellanae antiquis monumentis nunc etiam primum editis illustratae, Venice 1749, i. 229; see the corrected text in Bullarium Hellenicum. The letters of Pope Honorius III to Frankish Greece and Constantinople (1216-1227), ed. William Duba and Chris Schabel (Mediterranean Nexus, 3), Turnhout 2015, no. 218.

${ }^{4}$ Colin Morris, The papal monarchy: the western Church from 1050 to 1250, Oxford 1989, 441.

${ }^{5}$ Richard James Cleary, Pope Innocent III and the Greek Church (1198-1216): the theological teaching and the juridical, political and diplomatic practice of a pontificate which shaped the attitude of the papacy in regard to the Orthodox Churches through seven centuries, Rome 1993, 240. Similarly, Raymonde Foreville, Latran I, II, III et Latran IV (Histoire des Conciles Oecuméniques 6), Paris 1965, 257, accuses the council of making no viable preparation for dealing with matters concerning the Greek Church.

${ }^{6}$ These letters date to January and February 1216, but they are often incorrectly assigned to 1215, for two reasons: first, because the chancery did not begin the new year until March, privileges from January or February that bear the explicit year date of 1215 actually date to 1216 by our reckoning; second, Innocent's regnal year did not begin on the anniversary of his election on 8 January 1198 , but based on his consecration on 22 February, so 1 February in year eighteen, for example, is 1216 , not 1215.

${ }^{7}$ See recent overviews in Michael Angold, The Fourth Crusade: event and context, Harlow 2003; Angeliki E. Laiou (ed.), Urbs Capta: the Fourth Crusade and its consequences, Paris 2005; Jonathan Phillips, The Fourth Crusade and the sack of Constantinople, London 2005; Gherardo Ortalli, Giorgio Ravegnani, and Peter Schreiner (eds), Quarta Crociata: Venezia, Bisanzio, Impero Latino, 2 vols., Venice 2006; Pierantonio Piatti (ed.), The Fourth Crusade 
revisited: atti della conferenza internazionale nell'ottavo centenario della IV Crociata 12042004. Andros (Grecia) 27-30 maggio 2004, Vatican City 2008; Thomas F. Madden (ed.), The Fourth Crusade: event, aftermath, and perceptions, Aldershot 2008.

${ }^{8}$ See for example Brenda Bolton, 'A Mission to the Orthodox? The Cistercians in Romania', Studies in Church History xiii (1976), 169-81, reprinted in Brenda Bolton, Innocent III: studies on papal authority and pastoral care, Aldershot 1995, no. XVII.

${ }^{9}$ For an early example of this interpretation, see Jean Richard, 'The Establishment of the Latin Church in the Empire of Constantinople, 1204-1277', in Benjamin Arbel, Bernard Hamilton, and David Jacoby (eds), Latins and Greeks in the Eastern Mediterranean, Ilford 1989, 45-62, reprinted in Jean Richard, Croisades et États latins d'Orient, Aldershot 1992, no. VI. ${ }^{10}$ The letter is accessible in Bullarium Cyprium, b-40; Acta Innocentii III (1198-1216), ed. Theodosyj Haluscynskyj (Pontificia commissio ad redigendum codicem iuris canonici orientalis. Fontes, series 3, 2), Vatican City, 1944, 442-4, no. 206; and PL ccxvi. 823-6C, no. 30.

${ }^{11}$ From ASV, Reg. Vat. 8, fo. 142v, whence the partial edition in Acta Innocentii III, pp. 443-4, no. 206, attempts to publish the addressees in the East.

${ }^{12}$ King Demetrius of Thessaloniki, son of Boniface of Montferrat (b. 1205), was too young to be invited to the council, but it is safe to assume that the Kingdom of Thessaloniki's secular authorities would be represented by the emperor's emissaries, since Henry had succeeded in defeating a rebellion by the kingdom's Lombard nobles and had installed his own brother, Eustace, as regent.

${ }^{13}$ In Acta Innocentii III, 443-4, no. 206, Haluscynskyj reads 'Cavithien.' and guesses 'Corinthien.', but the manuscript actually has 'Corithien.' anyway. Haluscynskyj did not include Neopatras, not recognising 'Neupraten.' as an error for 'Neopatren.' For Serres, Haluscynskyj correctly interpreted 'Serten.' (not the Serta in North Africa) as an error for 
'Serren.' Haluscynskyj also lists 'Midicen.' among the eastern dioceses, without further details, not the Midica in North Africa, but perhaps understanding it as 'Maditen.', Madytos (Maydos), which was just a bishopric, although in 1228 it was referred to as an archdiocese. There are other possibilities in Latin Christendom, however.

${ }^{14}$ Achille Luchaire, 'Un document retrouvé', Journal des Savants iii (1905), 557-67, with the attendees from Romania listed on 562 and from Cyprus, mixed in with Sicily, on 563. Luchaire, 'Un document', 564, n. 4 reads 'Aradiensis' as a 'facile' error for 'Macrensis', Marki, but surely it is Herakleia, sometimes written 'Aracliensis' (but also 'Yracliensis', 'Eracliensis', and 'Heracliensis') with the 'cl' easily mistaken for a 'd'.

${ }^{15}$ For notes on the controversial Archbishop Giacomo Viadro, see Giorgio Fedalto, 'La chiesa Latina a Creta dalla caduta di Constantinopoli (1204) alla rinconquista Bizantina

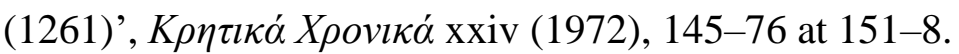

${ }^{16}$ Vetera monumenta Slavorum meridionalium historiam illustrantia..., ed. Augustin Theiner, Rome 1863, 47-70 at 63-70. Sixteen involving the church of Constantinople are catalogued in Leo Santifaller, Beiträge zur Geschichte des Lateinischen Patriarchats von Konstantinopel (1204-1261) und der venezianischen Urkunde (Historisch-Diplomatische Forschungen, Band 3), Weimar 1938, 186-7, nos 133-48.

${ }^{17}$ Karl Hampe, ‘Aus der verlorenen Registerbänden der Päpste Innozenz III. und Innozenz IV. I. Aus den letzen Jahren Innozenz III.', Mitteilungen des Instituts für Österreichische Geschichtsforschung xxiii (1902), 545-67 at 559-63, nos 13-18, from Paris, Bibliothèque nationale de France, lat. 11867, fos 36va-37rb.

${ }^{18}$ Vetera monumenta, 64, no. 22 and 67, no. 118; PL ccxvii. 241C; Antiquitates italicae medii aevi, ed. Lodovico Antonio Muratori, Milan 1741, v. coll. 835-6; Acta Innocentii III, 542, no. 4. 
${ }^{19}$ It is dated 1215 in the edition in Lucas David, Preussische Chronik, ed. E. Hennig, Königsberg 1812, ii. 204-8, and in most of the published summaries, including the excerpt in Bullarium Cyprium, no. b-41, but Regesta Pontificum Romanorum, ed. Augustus Potthast, Berlin 1874, i. 446, no. 5078, has the correct 1216.

${ }^{20}$ Vetera monumenta, 67, nos 118, 120-1; Antiquitates italicae medii aevi, v. coll. 833-4 (Pelagius) and 835-6 (Innocent); Acta Innocentii III, 542-3, nos 4 and 6; Bullarium Hellenicum, no. 180 (for earlier editions and summaries of Honorius' letters, see the entries in Bullarium Hellenicum).

${ }^{21}$ Vetera monumenta, 64 and 66 nos 47, 101, 105; Acta Innocentii III, 543, no. 5; Potthast, Regesta, i. 452, 454-5, nos 5160, 5211, 5231.

${ }^{22}$ Vetera monumenta, 65, nos 76-8, 80-2; Acta Innocentii III, 543, no. 3; Bullarium Hellenicum, no. 43.

${ }^{23}$ Vetera monumenta, 64, nos 39-3; Bullarium Hellenicum, nos 83-4.

${ }^{24}$ A Byzantine monastery called St Mary Agriotissa still exists near Limassol but, according to letters of Innocent IV, this monastery was dedicated to St Margaret in the thirteenth century. See The Cartulary of the cathedral of Holy Wisdom of Nicosia, ed. Nicholas Coureas and Christopher Schabel, Nicosia 1997, nos 107-8 and Bullarium Cyprium, nos e-1 and e-4. ${ }^{25}$ On this matter see Stanko Andrić, 'Baziljanski i benediktinski samostan sv. Dimitrija u Srijemskoj Mitrovici’, Radovi-Zavod za hrvatsku povijest xl (2008), 115-85, esp. 132-4. ${ }^{26}$ For Honorius' letter, see Pierre-Vincent Claverie, Honorius III et l'Orient (1216-1227): étude et publication de sources inédites des Archives vaticanes (ASV), Leiden 2013, no. 5. Laberia is thought to refer to the Judean desert, which was known to the Franks as La Berie or La Grand Berie (Denys Pringle, The churches of the crusader kingdom of Jerusalem: a corpus, Cambridge 1998, ii. 271-8, esp. 272), but it has also been suggested that the Palestinian monastery had moved to Berroia in northern Greece (hence Laberia) after the 
Muslim conquest of Jerusalem in 1187 (Filip van Tricht, The Latin renovatio of Byzantium: the empire of Constantinople [1204-1228], Leiden 2011, 313).

${ }^{27}$ Claverie, Honorius III et l'Orient, no. 24.

${ }^{28}$ Another monastery appearing separately, further down Theiner's list, under rubric 200, St Cucufacius, must refer to the Portuguese foundation dedicated to this saint.

${ }^{29}$ Vetera monumenta, 65, nos 56-8; Bullarium Hellenicum, nos 15-17.

${ }^{30}$ Vetera monumenta, 65, nos 69 and 70; Acta Innocentii III, 543, nos 1 and 2.

${ }^{31}$ Bullarium Hellenicum, nos 21, 54-5, 61, 230

${ }^{32}$ On Innocent and the patriarchate's rank, see William Duba, 'The Status of the Patriarch of Constantinople', in Alexander D. Beihammer, Maria G. Parani and Christopher D. Schabel (eds), Diplomatics in the eastern Mediterranean 1000-1500: aspects of cross-cultural communication, Leiden 2008, 63-92. For the topic's prominence in the debates, see Nikolaos Mesarites' report in Neue Quellen zur Geschichte des lateinischen Kaisertums und der Kirchenunion, ed. August Heisenberg, Munich 1923, iii. 34-6.

${ }^{33}$ Vetera monumenta, 66, nos 83-5, 87, 91; Hampe, 'Aus der verlorenen Registerbänden', 545-67, no. 14; Bullarium Hellenicum, nos 12, 28, 59, 105, 138, 188.

${ }^{34}$ Vetera monumenta, 64 and 66, nos 28, 92-3, and 95; Hampe, 'Aus der verlorenen Registerbänden', 562-3, nos 16-18; Acta Innocentii III, 541-2, nos 3 and 6; Bullarium Hellenicum, no. 264.

${ }^{35}$ Bullarium Hellenicum, no. 75.

${ }^{36}$ Bullarium Hellenicum, no. 23.

${ }^{37}$ Vetera monumenta, 64, nos 24-7. It is worth noting that, while reproducing Theiner's rubrics, Potthast mistakenly has Innocent III addressing Emperor Baldwin, rather than Emperor Henry (Potthast, Regesta, i. 451, nos 5143-5). 
${ }^{38}$ Vetera monumenta, 66, no. 90; Hampe, 'Aus der verlorenen Registerbänden', 561-2, no. 15; Acta Innocentii III, 542, no. 5 (= 543, no. 4).

${ }^{39}$ Vetera monumenta, 66, nos 88-9.

${ }^{40}$ Santifaller, Beiträge, 100-1, no. 2.

${ }^{41}$ Bullarium Hellenicum, no. 40.

${ }^{42}$ Bullarium Hellenicum, no. 185, listing previous editions, including PL ccxvi. 968-72C.

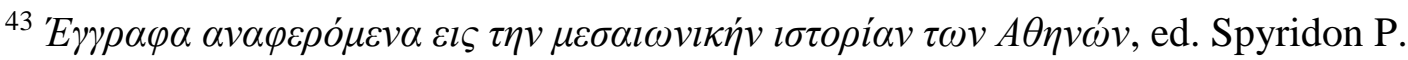
Lampros, Athens 1906, no. 11; Acta Innocentii III, no. 217; Acta Honorii III (1216-1227) et Gregorii IX (1227-1241) e registris Vaticanis aliisque fontibus, ed. Aloysius L. Tautu (Pontificia Commissio ad redigendum codicem iuris canonici orientalis. Fontes, series 3, 3), Vatican City 1950, no. 48; Bullarium Hellenicum, no. 87. Cf. Acta Honorii III, no. 94, and Bullarium Hellenicum, no. 127, from 1222: ‘... quam etiam felicis recordationis I. papa predecessor noster apostolico munimine roborans... predicti predecessoris nostri statutum super resignatione facta Ravenice tempore Generalis Concilii editum...'

${ }^{44}$ Vetera monumenta, 66, no. 86.

${ }^{45}$ Vetera monumenta, 66, no. 87; Bullarium Hellenicum, nos 22, 78, 119-20, 123, 125.

${ }^{46}$ See now Peter Gemeinhardt, 'The Trinitarian theology of Joachim of Fiore', Archa Verbi ix (2012), 9-33.

${ }^{47}$ Decrees of the Ecumenical Councils, ed. Norman P. Tanner, London 1990, i. 259.

${ }^{48}$ Decrees of the Ecumenical Councils, i. 235.

${ }^{49}$ Kenneth M. Setton, The papacy and the Levant, 1204-1571, Philadelphia 1976-1984, i. 30; Van Tricht, The Latin renovatio, 332.

${ }^{50}$ Van Tricht, The Latin renovatio, 321-32. 
${ }^{51}$ Filip Van Tricht, 'The Byzantino-Latin Principality of Adrianople and the Challenge of Feudalism (1204/6-ca. 1227/28: Empire, Venice and Local Autonomy', Dumbarton Oaks Papers 1xviii (2015), 1-18, at 13-14.

${ }^{52}$ The letter is published in Acta Innocentii III, 591-7, Appendix 1, n. 22, and excerpts are translated in Cleary, Pope Innocent III, 222-8.

${ }^{53}$ Published in Ecclesiae Graecae monumenta, ed. Jean Baptiste Cotelier, Paris 1686, iii. 495-520; and $P G$ cxl. 293-8C.

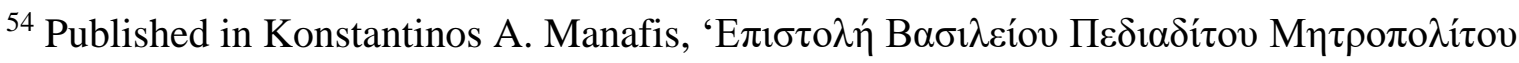

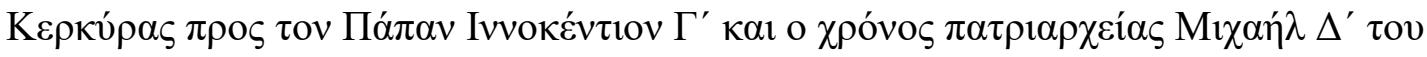

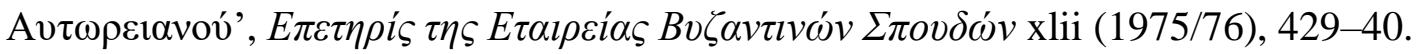
${ }^{55}$ Decrees of the Ecumenical Councils, i. 239.

${ }^{56}$ Bullarium Hellenicum, no. 222.

${ }^{57}$ Bullarium Cyprium i, no. c-47, listing earlier editions.

${ }^{58}$ Chris Schabel, 'The myth of Queen Alice and the subjugation of the Greek clergy on Cyprus', in Sabine Fourrier and Gilles Grivaud (eds), Identités croisées en un milieu méditerranéen: le cas de Chypre (Antiquité-Moyen Age), Rouen 2006, 257-77, reprinted in Christopher D. Schabel, Greeks, Latins and the Church in early Frankish Cyprus, Aldershot 2010, no. II.

${ }^{59}$ Luchaire, 'Un document', 561. 